\title{
Rise of the Digitized Public Intellectual: Death of the Professor in the Network Neutral Internet Age
}

\author{
Joshua Lange
}

Received: 18 July 2014/Accepted: 13 November 2014/Published online: 13 January 2015

(C) The Author(s) 2015. This article is published with open access at Springerlink.com

\begin{abstract}
The centralised discourse claiming ownership of 'knowledge' and 'higher education' seems to be declining as the decentralising discourse extolling open source software and informal social network communication are emerging: yet the two are complementary when higher education is seen as a commodity. Thus, in the internet age of the twenty first century there is no consistent narrative to identify what a 'higher education' consists of. J. F. Lyotard famously predicted in The Post Modern Condition that the commercialised computer age would 'sound the knell' of the professor. Lyotard understood that in order to begin to philosophise about higher education in an era of computerisation, the gatekeeper of knowledge role traditionally attributed to professors through a university title must first be rendered illegitimate. Lyotard did not envision, however, what a higher education might look like within the network neutral internet space, where the difference between 'higher' and 'public' education can be reduced through open accessibility to, and shared construction of, knowledge. Embracing a Socratic model of public discourse that openly challenges an epistemology of consensus, network neutrality has the potential to redefine the role of professors as fiduciaries of education across society, even globally. The resulting academic equality between professors and the public recreates the university as a boundless meeting space for public dialogue, and the professor as a digitized public intellectual.
\end{abstract}

Keywords Performance - Commodification - Democratic practices - Lyotard . MOOC $\cdot$ Public dialogue

\footnotetext{
J. Lange $(\bowtie)$

University College London, Gower Street, London WC1E 6BT, UK

e-mail: multipleintelligencesuk@gmail.com
} 


\section{Introduction}

Narratives controlled by state and corporate funders, particularly those advocating 'STEM' ${ }^{1}$ disciplines, define 'knowledge' and simultaneously 'higher education' scientifically. Their method of determination is economic deliberation and consensus: expenditure on higher education (HE) unrelated to university competitive advantage is wastage. Contrary to this discourse of centralised authority, construction and ownership of 'knowledge' and 'higher education' in modernised societies seems to promote a decentralising discourse with the emergence of search engines, open source software and social network media as widely accessible vehicles of transparent communication. Both directions of higher education give credence to Lyotard's (1984) prediction in the Postmodern Condition (hereafter cited by page only) of the computer age 'sounding the knell' of the professor (53). Lyotard argues that instead of providing the 'higher education' conceptualised in the old 'grand narratives' of emancipation and/or speculation (forwarded by Napoleon and Humboldt, respectively, 48-51), the university professor in the age of 'incredulity' is evermore subject to the single criterion of 'performance'-measured by market metrics and mediated by the forces controlling the 'inputs and outputs' of HE (29-32). Within this narrative, Lyotard saw 'experimentation in discourse, institutions, and values' (50) becoming devolved upon 'extrauniversity networks' rather than the university, with the university functioning to reproduce 'professional and technical elite' and tending to the mass of the 'addressees of knowledge.'

Indeed, the possibility of open access to organised course material through new technologies such as MOOC's (massive open online courses) seem to challenge the commoditisation of $\mathrm{HE}$ by distributing the construction, legitimation and location of knowledge away from the 'professor' towards network users and contributors. Nevertheless, the extremes of commoditisation and democratisation seem to complement one another rather than be at odds. Lyotard's reduction of these complementary extremes into narratives shows that they are insufficient to define a 'higher education.' Yet Lyotard did not envision what a higher education might look like within the network neutral internet space. Returning to the Socratic model of public discourse and invalidating the 'gatekeeper of knowledge' role attributed to professors within hierarchical institutions, network neutrality has the potential to reimagine the role of professors as fiduciaries of education across society, even globally. The resulting academic equality between professors and the public recreates the university as a physical and virtual meeting space for public dialogue: and the professor as a digitized public intellectual.

\section{The Inclusivity/Exclusivity Paradox of Network Neutrality}

Without language streamlined through online networks, where is the twenty first century self? Lyotard suggests that the weak concept of self exists only in a 'fabric of relations' which are ever more complex and mobile (15). Within this fabric, 'the

\footnotetext{
${ }^{1}$ STEM—science, technology, engineering, and mathematics.
} 
[dominant] system can and must encourage [transfer of knowledge] to the extent that it combats its own entropy; the novelty of an unexpected "move," with its correlative displacement of a partner or group of partners, can supply the [dominant] system with that increased performativity it forever demands and consumes' (15). This seems to philosophically identify how the internet functions within a marketcapitalist system. For example, the principle of 'network neutrality,' aimed at 'preventing restrictions on content, sites, platforms, types of equipment that may be attached, and modes of communication over the internet' (Google 2010) is central to the current 'move' towards free search engines, social networks, and open source software. Google, whose business model relies on network neutrality, has become so well-known that it is the newest verb, meaning 'to search for something on the internet.' Even academic publishing giant Taylor \& Francis now recommend that authors use GoogleScholar-friendly SEO (Search Engine Optimisation) key words as this open access search engine has become the primary search tool across the academic landscape.

The liberalisation of training through the internet has allowed millions of individuals, normally unable to attend a formal university programme, free access to cutting-edge theory and interactive training without a profession of faith in the authorities of that knowledge. Major collaborative initiatives are appearing without charge to global audiences via the internet, including classes delivered by professors at top-ranking universities. For example, one US university consortium now offers almost 40 semester-long 'MOOCs' or 'massive open online courses' with the slogan 'Education for Everyone'. And self-managing courses are offered without charge via computerised learning models, such as the 'Open Learning Initiative' sponsored by one Pennsylvania university. These latter types of courses, however, arguably lose the dialogic element between teacher-student (Wegerif 2007) and cannot be creditworthy without 'qualified' judgment on the other end, i.e., a 'professor' to evaluate student-developed content.

This borderless distribution of knowledge via MOOCs is a 'move' by institutions only possible because of network neutrality and the abrogation of institutional borders through dialogue between professors and the public. The contributing institution benefits from course-building information gathered from participants in open source courses, and applications such as wikis, websites and open source software are often developed by users themselves (Downes 2011). Thus the paradox of needing to de-institutionalise (inclusivity) in order to maintain institutional legitimacy (exclusivity): a paradox which arises due to the institution needing to combat entropy by incorporating mass data from open access users to inform their own exclusive degree programs. As a result, knowledge is 'produced' exclusively by professors and electronically delivered by institutions to unlimited global 'knowledge consumers' who then inadvertently feed knowledge-enhancing data back to the institution, which then legitimises its existence as a public good whilst enhancing its exclusive provision. Despite the inherent difficulties of culture, language, intelligence and content selectivity which make 'Western' 'education for everyone' a category error (DeVidts 2012), what has been termed 'crowd-sourcing' in marketing is fast becoming the new political, as well as educational, norm. 
Although network neutrality is an institutionally-derived 'move' towards enhanced market performativity, and Google seems to be monopolising the internet landscape, paradoxically network neutrality allows for at least two HE innovations that challenge the legitimation of institutional ownership of knowledge through the professor: (1) uncontrolled contribution of global internet users to knowledge production, and (2) proliferation of public access to learning materials offered by intellectuals and university consortiums. Without a universal or what Lyotard terms a 'totalising' narrative to support its self-ordained legitimacy, positional disruption of the professor might result in influence far beyond the walls of [his $]^{2}$ institution or peer-reviewed journal. Of course knowledge, and its predecessor epistemology, are never 'neutral'; but perhaps open access to fully-developed course materials via MOOCs and open access journals are geared, as Lyotard puts it, towards 'combating the entropy' of a self-legitimising knowledge hierarchy traditionally called 'higher education.' Even so, could market monopolies allow entropy to occur to further public dialogue? Probably not, as democratic values (inclusivity) and market performance (exclusivity) seem to have competing rationalities.

\section{Performance Rationality and the Paradox of the Open Access Course}

Now we shall turn to explore how Lyotard imagines that the deification of a technical rationality combined with market efficiency construes even autonomous, publicly-focused 'professors' as 'theory and knowledge producers'; a doomsday scenario where the professor is replaceable through philosophically reconfiguring HE provision into an efficient data collection and transfer system, legitimised by sophisticated measuring instruments. From the outset: narratives of performance rely on deliverables; it is impossible to 'deliver' a higher education; therefore the assumption that open access courses delivered to the public can comprise a higher education is propositionally false.

Lyotard defines 'performativity' as the goal of a systemtheorie, i.e., optimisation of the global relationship between input and output. Optimal monetised production outputs are a central feature, with dysfunctions seen merely as 'internal readjustments'. The only alternative to this kind of performance improvement is 'entropy', or decline (11). Visualise learning circulating along the same lines as money, Lyotard asks. The pertinent distinction would no longer be between 'knowledge' and 'ignorance', but rather, in verisimilitude with money, between 'payment knowledge' - units of knowledge exchanged in a daily maintenance framework (for survival purposes) versus 'knowledge funds' dedicated to optimizing the

\footnotetext{
${ }^{2}$ [He/his] in brackets is a purposeful and relevant challenge to the gender neutral term 'professor'. In English the neutralized 'his or her' disregards the historical record. Even though nowadays there are many female professors, the concept of professor originated in a male-only university environment, and males still hold the vast majority of these titles. The title itself should be critiqued from a gender perspective (see Nuyen 1995), and in my opinion, including the generic 'his or her' or changing to a generic 'her' or leaving out the brackets to the generic 'his' disregards the centuries-long struggle for women to even be considered for formal education, much less the title 'professor'; so I leave the brackets, highlighting the need for consideration of the lingering male connotation of 'professor' and the linguistic paternalism of the English language.
} 
performance of a project. In this conception, computerised means which 'optimise' predictable ends would delegitimise professors as agents of education and consequently invalidate the imaginary 'social contract' which legitimises 'the market' as a space for education, as its system requirement of quantifiable performances would inject optimisation through dialogic entropy.

However, the 'professor' is hardly a computer-enhanced function of selflegitimation governed and commoditised by financially strong and globallyinfluential university partners or brands in 'post-industrial' market societies. Notwithstanding, Lyotard identifies a more technical rationality at work in the production narrative: 'since performativity increases the ability to produce proof, it also increases the ability to be right' so 'scientists, technicians, and instruments are purchased not to find truth, but to augment power' through a single 'technical criterion' of performance (46) which assumes the technical instrument is more accurate than the human senses, as can be recognised by computerised valuations of universities on ranking scales based on 'quantity of $\mathrm{X}$ ' where $\mathrm{X}$ is defined by those holding the measuring tape as a superior performance item.

One of the emergent examples of Lyotard's technical performance rationality can be seen in the concept of 'MOOCs' or 'Massive Open Online Courses' which are offered gratis online and can be accessed by anyone with high speed internet. These courses have been available for over a decade through certain institutions and private philanthropic initiatives, but now that 'top-ranked' universities have taken them on and seemingly opened up their curriculum to the internet public, these courses suddenly are able to provide a conceivably-viable alternative to traditional on-campus or faculty-developed curriculum delivery and assessment: to the extent that Steve Kolowich reported in a May 2nd, 2013 Chronicle of Higher Education web article entitled Why professors at San Jose State won't use a Harvard professor's MOOC that philosophy professors at one university are fighting the administration over a decision to offer a MOOC from another as a credit-bearing alternative to their curriculum. The administration defends its position with recent experimental evidence that enrolled students who took a MOOC in electrical engineering scored higher on their exams than a traditional course. The computercontrolled MOOC is thus legitimised by a single example of technical performance uncritically generalised across disciplines.

And immediately delegitimised through its own legitimation. There is an underlying educational assumption that the 'brand name' prestigious university on the top of the rankings who produce and deliver the MOOC has superior pedagogy to the 'lesser ranked' universities taking on their MOOCs. This assumption is of course legitimised solely on the consensus of university administrators or technocrats who in many cases outnumber tenured faculty. But do not the results of the electrical engineering experiment 'prove' that university students are better off with a MOOC than a philosophy professor? Actually, assuming that electrical engineering, an applied science, correlates with the humanities only reveals a categorical fallacy in conceptualising education across domains. The performance criteria of memorising basic electrical engineering content and solving straightforward theoretical problems can only be transposed to conceptualising philosophical arguments in creative and individual ways through a technical rationality imposed 
on the definition of higher education. The categorically false assumption is revealed by Leibniz's Law: one set of exam performances (electrical engineering) can only be replicated to a different set of exams (philosophy) if both exams consist of identical elements, which is obviously not the case (to take this challenge into the modern assessment literature, readers are directed to the criteria of construct validity in Messick 1995). But perhaps the strongest critique of the MOOC experiment is that the administration has determined that 'delivery' of an acceptable score on an online exam performance equates to a higher education.

According to Lyotard, when market rationality defines the human as material subject, self-legitimised hierarchy aims to control 'human capital' through deterministic systems, and only those functions which support this system are acceptable. Under this techno-bureaucratic societal framing, graduates trained in theoretical narratives are unemployable. In response, funds allocated to programmes that produce unemployable graduates are removed; alternatively, study programmes are cancelled due to lack of applications, or entire faculties sacrificed for a greater business vision such as rankings prestige (Nuyen 1992; Bok 2003), or in the MOOC case above, the cost of a salaried professor. Lyotard suggests that with the continued materialisation of knowledge found in theories such as Marxism and Capitalism (Peters 2007), training in theoretical beliefs will cease, despite their desirability as topics of inquiry; and professors will be made redundant as they are unnecessary for the delivery of skills training. Consequently, the invisible hand of hegemony reduces the professor from autonomous public educator to a cog, a manager, in principle replaceable by management software.

Two clear examples of how Lyotard's 'input and output' performativity narratives delegitimise professors are through 'word count' and 'scheduled supervision' policies controlled by arbitrary software surveillance. Word processing software calculates each word/character/symbol with such precision that a writer can always see a calculating icon on the screen. Arbitrary and oftentimes confusing limitations of 'word volume' are justified through an efficiency principle confining both students and professors to policy that someone 'out there' determined. Students must 'in X number of words, evaluate' something that took the (oftentimes concise) original writers several volumes to consider. Consequently, the $\mathrm{X}$ word essay as the default mode of student performance evaluation controls the depth of inquiry on any given subject through arbitrarily restricting the amount of coherent thought that can be communicated by the student and simultaneously assumes negative consequences for non-compliance. Professors, on the other hand, oftentimes elaborate insufficiently and incoherently (Feak 2009) on a student or peer's work without penalty. Likewise, professors' time is clocked in the name of 'accountability' through computerised surveillance applications which arbitrarily schedule and count doctoral supervision for each professor and candidate, systematically sending 'email reminders' of fictional appointments. I have received two such fictional appointments recently and a subsequent email from the interlocutor saying 'disregard.' Paradoxically, the socio-political 'free market' discourse could claim these computerised controls as democratic progress through invoking references to social justice: for example, for monitoring 'equality' of provision to all students whilst efficiently monitoring 'fairness' through calculating worked hours. 
What is missing, however, is the ability to counter these claims within the allencompassing rationality of the narrative. Is progress simultaneously confinement? In other words, are counted words comparable to meaningful utterances? Are hours at work comparable to hours worked if your job is a thinker? Knowledge is anything but 'internal' with such 'externally determined' borders. The failure of the professor continuing as the disseminator of knowledge in the internet age is that the transcendent narrative meant to establish knowledge in the university only reifies the power of its self-legitimised administration: 'knowledge and power are simply two sides of the same question: who decides what knowledge is, and who knows what needs to be decided? In the computer age, the question of knowledge is now more than ever a question of government' (8).

The above scenario of HE market reductionism seems to expose the conflicted direction of higher education in the information age, that serves not only theoretically but practically to delegitimise the professor. Pull and push forces moving towards and away from centralisation range from student-developed 'open source' courses and freely accessible material offered by public intellectuals to visions of 'assembly line' HE models controlled by computerised administration. Sometimes there is little distinction between the two. Both open-source and privatized interests construct a discourse of the 'delivery' of an electronic 'product' within an 'institution' of higher education. This discourse only reifies higher education as a closed, deterministic system: a logical impossibility if higher is defined as going above.

\section{The Higher Education Paradox of Flipped Classrooms and Digital Taylorism}

Video lectures with high quality sound, pause, replay, and download capability are already an inescapable mode of knowledge transfer in institutionally-determined HE. For example, Prober and Heath (2012) cite many experiments from their university in California, such as a Computer Science course broken down into 10-15 min video segments with constant online quizzes and several Medicine lectures transformed into short online video presentations prior to the classroom activities. The authors suggest that these approaches have increased student satisfaction and engagement. They promote a 'radical' shift away from the lecture: 'in an era with a perfect video-delivery platform...why would anyone waste precious class time on a lecture?' into a 'flipped-classroom model', where 'students absorb an instructor's lecture as homework in a digital format, freeing up class time for a focus on applications. By recognising the viability of new digital media to replace the lecturer as knowledge transmitter, however, what Prober and Heath promote is more than online self-calculating quizzes or video lessons: philosophically they admit their own delegitimation as lecturers.

Gombrich (2011) takes the delegitimation of the lecturer to its logical conclusion on his dual $\mathrm{Ba} / \mathrm{BSc}$ programme in London based on what can be described as a 'crowd-sourcing' model of higher education: 'lectures as a way of delivering content are over'. His model requires that each fee-paying student submit three questions to the lecturer based a lecture recorded in advance and placed on a Virtual 
Learning Environment (VLE). The lecturer then collates all the questions and chooses the most frequent 10-30 questions to address. Gombrich suggests that this can be student-led and accomplished almost instantly through the VLE. The $1 \mathrm{~h}$ slot that had been used for the lecture is now a full class discussion, "with the lecturer leading and discussing all the issues the class wanted to discuss'. Essentially, students would have 2 or 3 h of weekly forum discussions with 'leading academics' based on questions that interest students.

Gombrich suggests that his model could easily accommodate 180 students per lecturer. In classes that large, this democratic-institutional model could only situate knowledge into the quantified 'interests' of the students through frequency, rather than the disciplined expertise of the professor-the one individual who could potentially sort the questions in a meaningful way, such as that one in the bottom of the pile which might lead to an alternate way of understanding the material. When applying the market efficiency principle, one can see the discussion leader function completed online through a social network, simply due to the practicalities of such large forums. The greatest threat to this model is perhaps not the surrogacy of the professor to the student, however, but customer majority rule. If customer majority rule leveraged control of the internet, thus 'owning' this dissemination of knowledge, intellectuals would lose their public value and return to their professor high chairs where they offer the exact same videotaped courses as a 'payment for knowledge' exchange: in other words, a return to their insular institutional norms and private knowledge communities at the expense of democratic knowledge exchange with the public. To cite John Stuart Mill $(1859,18)$ from On Liberty: 'If all mankind minus one were of one opinion, mankind would be no more justified in silencing that one person than he, if he had the power, would be justified in silencing mankind.'

A more extreme position towards commoditisation of higher education in the information age, commonly called 'new' or 'digital' Taylorism ${ }^{3}$ (Au 2011; Parenti 2001) can be observed through the below extended quote, excerpted from a blog titled 'The economic advantage of online education' posted on the Huffington Post, 16 February 2012 by the dean of a prominent US faculty, outlining an 'assembly line in higher education':

Instead of one professor creating and delivering a course; we see the following lineup of education workers: A) course designers, B) content developers, C) course facilitators, and possibly, D) tutors and graders. The course designer, Worker A, is an instructional technologist, perhaps with a master's degree in education, expert in learning objectives and assessment of learning. The content developer, Worker B, is the scholar in the field who will populate the course website with readings, notes, taped lectures or speeches, assignments, etc. The course facilitator, Worker $\mathrm{C}$, is the instructor or mentor, who interacts with students and guides their learning. Tutors (Worker D, or an outsourced service) can be utilized for learners with more than average learning

\footnotetext{
${ }^{3}$ Under Taylorism, the role of the manager is to break down tasks and give specific instructions to workers, and must have the right tools in order to do their job. In turn, workers only role is to do exactly as they are told and fill whatever quota they are given.
} 
challenges; eliminating the need for office hours. And finally, in what can be described as icing on the cake for faculty considering whether to go online, the graders (Worker D, again) are called into objectively evaluate student submitted work, using rubrics provided by the course designer and content developer. Theoretically, this lowers the cost of higher education by reducing the number of hours required of the scholar in the education process, and replacing that scholar with professionals who specialize in the various other activities; and who are normally lower paid than a chaired professor in finance. Moreover, it frees up the scholar to focus on the research, which justifies that high salary.

Professor Gilbert then compares the cost savings of her proposed model with the 'traditional model' suggesting massive financial savings if more than 40 enrol, and closes with: 'in asking yourself whether online learning and the production model described here will catch on, I think the answer is obvious. And, If history repeats itself, and if the lessons of economics are to be believed, the U.S. will be better educated at more affordable tuition rates, and scholarship will not suffer in the least...'

Why stop at the death of the lecturer? Since the aim is to use 'cost-efficient', easily accessible video technology to engage students-as-customers, the videos could be made by paid actors offering charisma and clear pronunciation; and the classroom activities could be delivered by external professionals or consultants actually working in the field. These external contributors could even consult via a free social network on their mobile phones: new 'cloud computing' platforms and 'digital archives', for example, enable users to access information anywhere, in any quantity, delegitimising the professor and the university library as the site-specific gatekeepers of accepted scientific knowledge. Passwords protected by the university are unnecessary for information transfer in the cloud, as the content could be contributed from a different source than the university yet potentially produce the same or better exam results for the student entirely absent a professor.

As research-intensive universities embrace a corporate governance and managerial model (Gibbs, Knapper \& Piccinin, 2009), tasks can be expected to be singularised, and expensive professors that teach other than job-ready competences (i.e., broad theoretical knowledge) made expendable through efficiency narratives (Peters 2007). To illustrate, a quasi-experiment with a large sample of Physics undergraduates compared two sections of a course, one taught by Nobel-Prize winner and another taught by teaching assistants. The results showed that the section taught by assistants produced higher course ratings, attendance, and test scores: students averaged $74 \%$ as opposed to $41 \%$ (Deslauriers, Schelew \& Wieman 2011). Although these results represent a quite limited study, computerised administration in this paradigm offers 'customers' professor performativity; and if the professor cannot perform, an assistant making minimum wage will.

Although the efficiency of corporate performativity increases percentages and dethrones the professor-as-lecturer by distributing accepted scientific knowledge via video, cloud computing and social networking; or saving human 'capital' by providing 'Workers $\mathrm{ABCD}$ ' in an 'online learning production model', reliance on 
information accessibility alone hardly guarantees 'better educated' citizens. Who in the above design provides intellectual stimulation beyond digitalised a posteriori research data? Who provides what Greeks called 'aporia' or puzzlement resulting from thought-provoking dialogue? Who provides the counterclaim to an ethic of humans as capital! In other words, financially cost-efficient 'assembly line' HE could theoretically reproduce certificated 'knowledge workers' only at the incalculable expense of the types of dialogue which arguably create an educated public.

\section{Illegitimate Twins: The Professor and the Public Intellectual}

I recently posed the following question conversationally to several undergraduate students of politics in a Eurasian campus café: 'Which university was Socrates a professor at?' The responses worth mentioning were 'Greek' or 'Athens' university. Every student without exception answered positively as if it was certain that Socrates was a professor. Of course the first university was consecrated in Bologna, Italy in 1088 (de Ridder-Symoens 1992) by the Catholic Pope more than 1,400 years after Socrates' death. Furthermore, Socrates was hardly part of institutional education: he taught anyone on the street who would listen, a prototype of what is referred to in modern times as the 'public intellectual'. This general knowledge is relatively meaningless as a philosophical inquiry; however, as an educational inquiry several questions emerge about the 'professor': why would students equate 'Socrates' with 'professor'? In what context did the 'professor' emerge, and why does the 'professor' seem to substitute or accentuate the philosopher or great thinker? Moreover, is 'higher education' symbiotic with the institutionally-dependent professorship?

\section{Professor: Titled Thinker or Scientific Priest?}

The Oxford English Dictionary subjects 'professor' to many definitions, some broadened to its faith-based etymology, 'A person who makes open declaration of his or her feelings or beliefs, or of allegiance to some principle' and others narrowed to a university title, but all dependent on a relationship between individuals and the social status of their beliefs. This paper narrows the 'professor' to the hierarchicalinstitutional sense: 'A university academic of the highest rank; specifically the holder of a university chair in a specified faculty or subject'. The professor in this sense is symbolic of what Lyotard terms a 'metanarrative', which Lyotard defines as 'a totalising discourse of value' — such as religion or science-that relies on a 'grand narrative' or 'transcendent and universal truth' (xiv). One clear example is the scientific case the Enlightenment ideal of reason over mythology: the Enlightenment discourse of induction and deduction reduces the religious claim of faith-basedknowledge to absurdity. So, one 'metanarrative' trumps another. Lyotard sees the 'professor' as a function which legitimises 'totalising discourses' such as religions or science, since metanarratives indeed require spokespersons who speak from some 
sort of legitimate authority. Lyotard assumes that a professor is required by the calling of [his] vocation to come up with a theory (narrative that supports the legitimacy of the metanarrative), then to spread these theoretical views to the students. In turn, students learn what is acceptable as science and knowledge. However, according to Lyotard's Post Modern Condition when a theory becomes unnecessary to support the metanarrative, the legitimising-of-knowledge function of the professor vanishes (Nuyen 1992).

The complex historical question of the emergence of the titled, legitimised thinker is well beyond the scope of this essay, but simply stated: Christianity is the origin of the university and its corollary, the professor. The vast majority of 'topranking' universities over 100 years old in Europe or the US were founded by Christians, and beyond the revealing architecture, Christian rituals still permeate. For example, according to Anne Lonsdale, former Pro-Vice-Chancellor of Cambridge University, during an October 2011 face-to-face conversation, graduating bachelor's degree students to this day must kneel and receive a blessing from the Vice-Chancellor in Latin: 'by the authority committed to me I admit you to the degree of $\mathrm{X}$ in the name of the Father and of the Son and of the Holy Spirit.' Of course the title Pro-Vice-Chancellor in most universities refers to 'professor' rather than 'priest', but any ambiguity through the mask of scientific liberalism is unable to deny the professor functioning as gatekeeper (representative) of some sacred knowledge (in God's name), whether that ultimate-authority is the Holy Trinity or the Scientific Method.

Science and Christianity, then, have a common feature: both can be framed as institutionalised stories legitimised by those in high chairs. Each story legitimises existing power relations through appropriating reasons and explanations to the narrative, which is determined to be 'universal truth' (xiv). For example, in Feuerbach (1843) showed how the Christian narrative was not an explanation but a legitimation of the norms of Christian society. On the other end of the spectrum, Nietzsche $(1982,450)$ philosophised that science is a religious paradox from which even Nietzsche cannot escape: 'It always remains a metaphysical faith upon which our faith in science rests - that even we devotees of knowledge today, we godless ones and anti-metaphysicians, still take our fire too from the flame which a faith a thousand years old has kindled: that Christian faith, which was also Plato's faith, that God is truth, that truth is divine.' And in a similar critique of a metaphysics of the transcendence of science, Lyotard sees science as another language game dating back to Plato's cave allegory where 'knowledge is founded on the narrative of its own martyrdom' (28).

More contemporary philosophers, respectively Žižek and Milband, seemingly argue from opposing viewpoints on the atheist/theist debate, yet Davis $(2009,8)$ finds consensus in their deliberation: 'Reason functions in this atheistic/theistic debate in a very limited, even reductionist way as it becomes the final arbiter of all truth forced into propositional form and thus sundered from everyday life'. In Lyotard's conception of this problem, however, the metanarrative of Christianity has been upended by the metanarrative of science, but since 'scientific knowledge is a kind of discourse' (3) the 'professor' as a believer and proponent of scientific knowledge plays a gatekeeper role in the legitimation of accepted 'truth' through 
the discourse [he] promulgates: like Plato's protagonist who escapes and returns, this is a story [he] must inevitably deny to uphold the universal narrative of 'knowledge as liberating progress' obtained solely through [his] tutelage.

Who, then, decides the conditions of truth? According to Lyotard 'There is no other proof that the rules are good than the consensus extended to them by the experts' (29). Lyotard claims that narrative knowledge, to become legitimate, must combine at least two criteria: institutional deliberation of what has truth-value, and formulaic prescriptions that have the status of norms. This 'consensus' thinking is in line with Habermas's $(1984 ; 1987)$ conception of 'communicative action' which aims to achieve mutual understandings as a basis to coordinate emancipatory social action. However, Luhmann (2013, p. 205) conjectures that the 'speech act' underlying Habermas's theory mistakes the 'mere conveying of a message' for communication; whereas in Luhmann's systems theory the 'unity of communication' requires an understanding recipient. Lyotard problematizes this further by suggesting that consensus is reached according to the requirements of institutional deliberation and the methodology to be engaged, i.e., a narrative of a narrative. For Lyotard, following Wittgenstein, the principle of a 'universal metalanguage is replaced by the principle of a plurality of formal and axiomatic systems capable of arguing the truth of denotative statements' (44). Lyotard asks: how is it possible to do away with narrative by using narrative? (xix) and suggests 'What used to pass as a paradox in the knowledge of classical and modern science can acquire a new force of conviction and win the acceptance of the community of experts' (44). One glaring example of this reduction of truth into consensus can be seen through the self-legitimising discourse of a knowledge hierarchy found in so-called 'world' rankings.

University rankings are sustained and promulgated by hierarchies of expert communities, and consensus won at the expense of the individual partners constituting those communities becomes a cycle of de facto legitimation (47) of the self-ordained elite at the top of the knowledge hierarchy. Universities rank themselves competitively according to how many professors at a given institution are Nobel Prize winners, their grant funding and easily 'self-plagiarised' (Robinson 2012) publication quantity (in journals often edited by professor's friends and colleagues), ${ }^{4}$ which legitimises their opinions and teaching methods to prospective students through the media, who create what marketers call 'value propositions' for these institutional practices through internet searchable computerised ranking systems based on the same criteria; the self-legitimised practices of these 'worldleading' institutions are then promoted by the institutions and their camp followers, and delivered to a group of profiled students filtered through computerised 'aptitude' testing instruments legitimised by the same top-ranking universities. Subsequently, powerful corporations and governments employ human resource management software which identifies 'key terms' in résumés such as names of the most competitive university 'brands' or standardised aptitude test scores-despite the cultural bias invalidating these constructs (Rindermann 2007)_ giving arbitrary control to the computer to filter candidates for positions of decision-making power.

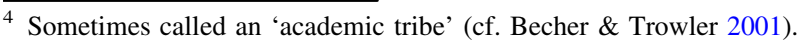


These computer-filtered candidates, after gaining experience are selected for influential positions partially because of their easily recognisable 'qualifications' from top-ranked universities with high-profile professors. These financially-wealthy and influential alumni then reinvest into their alma maters, allowing for the purchase of evermore accurate technology which advances their first claims to original knowledge. Repeat.

\section{Rise of the Digitized Public Intellectual}

Without the professor who seeks truth beyond a consensus of norms, how then can the hegemony of rankings be challenged? One scenario: without a professor who educates beyond the knowledge determined by an institutional elite, the rankingscontrolled research institution will remain as the 'higher' educational power through determining and bracketing 'knowledge' using the cycle found in the previous section. This uncontested knowledge will then be delivered down to the online masses through closed-system methods that test facts (such as automated quizzes) without really educating the public into the more abstract conceptual knowledge achieved through negotiating truth with disciplined intellectuals. The result is a socalled 'higher' education delivered to the public by a self-legitimised knowledge hierarchy that systematically prevents public refutation or challenge to established norms. My contention is that this quite plausible outcome of public higher education in the internet age could easily overlook the essential epistemological concept of 'paralogy' or 'dissensus' (60), defined by Lyotard as an opposition to consensus that consists in the questioning of assumptions governing established practices and the emergence of heterogeneous practices.

If higher education is accepted as a product delivered to student customers, public engagement becomes public relations. The 'free online course' becomes a marketing tool with what venture capitalists call exponential multiplier effects-a commodity, which serves the financial bottom line much like rankings: by uncritically amplifying the institutional 'brand' in the minds of the public. Lyotard predicted that knowledge-defined as research and the transmission of acquired learning-would increasingly tend towards an exchangeable commodity, thus losing its value as an 'end in itself' and becoming the major stake in the worldwide competition for economic power: 'along with the hegemony of computers comes a certain logic, and therefore a certain set of prescriptions determining which statements are accepted as "knowledge" statements...anything in the constituted body of knowledge that is not translatable [into computer language] will be abandoned' (4). However, even if computers could lead humans towards 'dissensus' as a result of an ad infinitum attempt of perfect information searches mediated by the global internet public, computers could not lead humans into public concern. Computers are only tools of information transfer-they do not invent culturallymediated goals that 'originate in prescriptive and evaluative statements that the computer cannot correct in the course of its functioning' (17). Thus, the 'free' dissemination of courses created by professors through open source educational 
technology and 'delivered' by top-ranked institutions cannot substitute an education of speculation and/or emancipation.

These new spheres of computerised education cannot exist as binary functions of pre-packaged theory 'given' down to the public, but they can be new epistemologies mediated by public intellectuals and serve the educational needs of the public. Jacoby $(2000,5)$ describes the 'public intellectual' as a writer and/or thinker who addresses a general and educated audience. Although Jacoby laments the 'last intellectuals' from a bygone era, nowadays there are many intellectuals who freely share their ideas to the wider public over the internet. Public intellectuals come from every field of human inquiry, yet are united by the common ethical position, idealised by radical educationalist Paulo Freire, that any contribution to knowledge should be freely accessible even to an illiterate audience, and those audiences should be able to inform the construction of knowledge.

John Michael (2000) suggests that intellectuals like Stephen Hawking, Cornel West, and others who commit to an active role in public life are the best result of the Enlightenment project. Michael suggests that although Enlightenment narratives may be incredulous, the crucial ideas of 'reason, justice, and equality' still frame the political and cultural work of intellectuals today. What differentiates the 'digitized public intellectual' from the 'professor,' however, is hardly 'reason, justice, and equality' in a self-legitimising institutional sense; digitized public intellectual faith can be described as moral faith in the ideal of knowledge distributed over the network neutral internet, and the intellectual as a fiduciary of digitally-enhanced borderless education. Thus, the disruptive 'move' of network neutrality ${ }^{5}$ meant to enhance capitalist institutions through opening markets, mixed with an ethical belief in free distribution and interpretation of knowledge has resulted in 'open source' construction of new knowledge via the internet. In the most progressive political moves the role of the professor is morphed from 'education authority' into 'digitized public intellectual.' This structural equality between teachers and students directly challenges what Lyotard terms the 'totalising effects' of a market discourse governed by state and private hierarchies.

Conceptually, then, from an ethic of public concern and a network neutral platform the digitized public intellectual merges two mutually exclusive concepts: depth of content with ease of understanding. Otherwise a higher education built on public dialogue is impossible because the professor is inaccessible outside of the walls of [his] institution. The below principles identify how digitized public intellectuals can, and are emerging around the world in the network neutral internet age of higher education.

The digitized public intellectual speaks openly about their ideas, in a way that the public can understand and interpret for themselves

This dates back to 1517 A.D. when Dr. Martin Luther, a lecturer in Wittgenstein Germany, challenged the Catholic authorities by including in his 95 theses: (90) 'To

\footnotetext{
5 The principle of 'network neutrality aims at 'preventing restrictions on content, sites, platforms, types of equipment that may be attached, and modes of communication over the internet' (Google 2010).
} 
repress [the above written] arguments and scruples of the laity by force alone, and not to resolve them by giving reasons, is to expose the Church and the pope to the ridicule of their enemies.' Luther and his contemporaries argued that the Bible should be written in plain language, and like the digitized public intellectual assumed two things: (1) the intelligence of the laity, or the public, and (2) the public's right to participate in the construction of knowledge through interpretation. Today, intellectuals like Michael Sandel (ethics) or Richard Dawkins (biology) can be found openly on the internet engaging with the public on important political issues - not through rhetoric and spin-but by clear reasoning, logic and an ethical belief in the value of shared truth in a language that the public can understand and interpret for themselves. To use Freire's terminology, the 'pedagogy of the oppressed' can emancipate the oppressed only when the oppressed comprehend the terms of reference.

\section{The Digitized Public Intellectual Creates an Ever-Widening Public Dialogue}

One example is Scott Thornbury, whose 'A-Z of ELT' is disseminated globally via a free blog site to language teaching professionals, who comment on his ideas, then Thornbury responds to the comments creating dialogic reciprocity and uses ideas from the commenting field professionals to inform his university classes. Importantly, some of Thornbury's posts are generated from students in his classes, who also receive the posts in their email inbox and oftentimes engage with field professionals. This reciprocal, open communication channel creates ever-widening spirals, or spheres of dialogue (depending on how one conceptualises it) that serve to help the students, the field professionals, and to use Luther's terminology above - 'the laity' — to speculate beyond epistemological boundaries.

\section{The Digitized Public Intellectual Reaches an Unlimited Community of Practice}

The empirical concept of 'communities of practice' is underpinned by the philosophy that "knowing is an act of participation in "social learning systems", (Wenger 2000), and the internet has opened new boundaries of a higher education community. In addition to publishing in open-access online journals which often have the same peer-reviewed rigour as their exclusive counterparts, digitized public intellectuals find new ways to engage with communities of practice. A J Cann, for example, in 2012 presented one of his theories at a major conference via distance through 'Google Hangout' with the reason 'to lessen his carbon footprint', and then posted his presentation online to an open access platform, where any internet user can have a 360 view-even watching the original audience move around at any time without registering, paying, or subscribing. Slightly different in focus to the A-Z blog mentioned above, these openly-shared conference presentations target specific communities, thus offering the most cutting-edge ideas and results of empirical studies in the discipline in real time without requiring institutional subsidisation of expensive travel to conferences or subscription to for-profit journals. 
The Digitized Public Intellectual Makes Their Most Significant and Original Material Accessible to Anyone on the Internet

This criterion: controversial, prolific material. David Harvey, for example, offers a comprehensive set of courses on Marxist thought to the internet public-not just 'entry level' ones like many university-controlled MOOC courses. Living out these ideals of public engagement with intellectual ideas, Harvey and other professors from nine New York universities gathered on May 1st, 2012 to collaborate with the 'Occupy Wall Street' movement and offer a one-day 'free university' promoted through the internet and open to all. Amongst the topics delivered in a language that the public could understand and creating an ever-widening public dialogue was the stability of the current economic system, something that affects everyone, ensuring that those with the smallest voice had the opportunity to engage with the greatest thinkers and their most significant ideas.

The Digitized Public Intellectual Asks the Public to Create the Research Questions, Determine the Best Instruments, and Conduct the Research That Affects Them

This has a relation to the 'participatory approach' to educational research, but with a digital twist. The 'Extreme Citizen Science' group led by Muki Haklay is concerned with citizens becoming scientists. They have already shown concerned citizen groups how to use GPS technology to calculate noise pollution around Heathrow airport, and hunter-gatherer groups in Africa how to use mobile GPS technology to identify, record, and thus protect their diminishing sacred trees against an onslaught of corporate and government deforestation programmes. This engagement with the public does not require subscribing to an 'emancipatory' truth paradigm where the disenfranchised magically receive political equality; it is simply the drawing in of human collectives to an education beyond prescribed delivery.

Educationally speaking, the self-legitimising institutional superstructure sustained by an imaginary hierarchy of knowledge-and its spokesperson the professor - can be found wanting in what Lyotard coined 'The Postmodern Age', or the age of incredulity towards universal narratives of truth. This has coincided with the rise of the 'digitized public intellectual,' who is more than a 'knowledge worker': she or he is a public fiduciary of knowledge and negotiator of truth that uses the internet as a tool to educate the public through challenging dialogue. No longer is the monster intellectual behind the protected walls of the elite institutions, but rather their humanity is revealed through open dialogue on the internet where the digitized public intellectual learns as much as they teach and their knowledge grows in proportion to their public contribution. The knowledge produced by the digitized public intellectual challenges the commodification of epistemology by tearing down the walls of hierarchy, particularly those walls created by money and sophisticated measuring instruments. 


\section{Conclusion}

The valorisation of net neutral mobile social networks as a remedy to the 'totalising' effects of market reification implies that there will be more and more attempts for higher education to be 'delivered' through the norming of open source freeware uncontrolled by the self-delegitimising hierarchies of higher education that have existed since the first Catholic university. Paradoxically, through the notion of 'net neutrality' meant to 'liberalise' markets thus produce more 'shareholder value', the market metanarrative ensuring the positional significance of the professor has functionally imploded. [His] replacement is supposedly the redistribution of knowledge-as-power to any autonomous learners and teachers who can access a network neutral, high speed internet. Yet this unlimited student body can educate themselves only to the limits of the institutional narrative. A higher education of the internet age must therefore include the 'digitized public intellectual' as catalyst of change. This identifiable intellectual actor is neither subject to nor legitimised by her/his gatekeeper function within the evermore mechanised system of calculable 'knowledge' inputs and outputs found in the top-down metanarratives of institutional consensus. Rather, through creating and responding to challenging dialogue that leads to public 'dissensus' and puzzlement, the digitized public intellectual creates ever-widening spheres of dialogue, ushering in a new era of higher education beyond the prescribed delivery of knowledge. Socrates has thus been digitally reborn.

Open Access This article is distributed under the terms of the Creative Commons Attribution License which permits any use, distribution, and reproduction in any medium, provided the original author(s) and the source are credited.

\section{References}

Au, W. (2011). Teaching under the new Taylorism: High-stakes testing and the standardization of the 21st century curriculum. Journal of Curriculum Studies, 43(1), 25-45.

Becher, T., \& Trowler, P. (2001). Academic tribes and territories: Intellectual enquiry and the culture of disciplines (2nd ed.). Buckingham, UK: Open University Press.

Bok, D. (2003). Universities in the marketplace: The commercialization of higher education. Princeton, NJ: Princeton University Press.

Davis, C. (Ed.). (2009). The monstrosity of Christ: Paradox or dialectic. Cambridge, MA: MIT Press.

De Ridder-Symoens, H. (1992). A history of the university in Europe. Volume 1, universities in the middle ages. Cambridge, UK: CUP.

Deslauriers, L., Schelew, E., \& Wieman, C. (2011). Improved learning in a large-enrolment physics class. Science, 332, 862-864.

Devidts, K. (2012). Online education: Kant \& the Tyranny of Democracy. Essay Outline. Retrieved April 23, 2012, from http://vle.exeter.ac.uk/mod/forum/view.php?id=171063.

Downes, S. (2011). Connectivism and connected knowledge. Huffington Post. Retrieved June 21, 2012, from http://www.huffingtonpost.com/stephen-downes/connectivism-andconnecti_b_804653.html.

Feak, C. (2009). Culture shock? Genre shock? English for Specific Academic Purposes: Proceedings of the 2009 BALEAP Conference. Reading, UK: Garnet Education.

Feuerbach, L. (1843) The essence of Christianity. (G. Eliot, 1854 Trans.). Retrieved May 15, 2012 from http://www.marxists.org/reference/archive/feuerbach/works/essence/index.htm.

Gibbs, G., Knapper, C., \& Piccinin, S. (2009). Departmental leadership of teaching in research-intensive environments. London: Leadership Foundation for Higher Education. 
Gombrich, C. (2011). Opinion: Lectures as a way of delivering content are over. University College London Teaching and Learning Portal. Retrieved May 21, 2012, from http://www.ucl.ac.uk/ teaching-learning/news/carl-gombrich-flipping-the-lecture-theatre.

Google (2010) Facts about our network neutrality proposal. Public Policy Blog. http://googlepublicpolicy. blogspot.com/search/label/Net\%20Neutrality. Accessed Aug 2013.

Habermas, J. (1984) [1981]. Theory of communicative action volume one: Reason and the rationalization of society (T. A. McCarthy, Trans.). Boston, MA: Beacon Press.

Habermas, J. (1987) [1981]. Theory of communicative action volume two: Liveworld and system: A critique of functionalist reason (T. A. McCarthy, Trans.). Boston, MA: Beacon Press.

Jacoby, R. (2000). The last intellectuals: American culture in the age of academe (2nd ed.). New York: Basic Books.

Luhmann, N. (2013). Introduction to systems theory. Cambridge, UK: Polity.

Lyotard, J.F. (1984). The Postmodern condition: A report on knowledge. In Theory and History of Literature, Vol. 10. Manchester: Manchester University Press.

Messick, S. (1995). Standards of validity and the validity of standards in performance assessment. Educational Measurement: Issues and Practice, 14, 5. doi:10.1111/j.1745-3992.1995.tb00881.x.

Michael, J. (2000). Anxious intellects: Academic professionals, public intellectuals, and enlightenment values. North Carolina: Duke University Press.

Mill, J.S. (1859). On Liberty. 2001 ed. Ontario, CA: Batoche Books. Retrieved May 25, 2012, from http:// socserv2.socsci.mcmaster.ca/econ/ugcm/3113/mill/liberty.pdf.

Nietzsche, F. (1982). The Gay science. Book V. In The Portable Nietzsche. New York: Penguin.

Nuyen, A. T. (1992). Lyotard on the death of the professor. Educational Theory, 42, 25-37. doi:10.1111/j. 1741-5446.1992.00025.x.

Nuyen, A. T. (1995). The rhetoric of feminist writings. Philosophy and Rhetoric, 28(1), 69-82.

Parenti, C. (2001). Big brother's corporate cousin: High-tech workplace surveillance is the hallmark of a new digital Taylorism. The Nation, 273(5), 26-30.

Peters, M. S. (2007). Knowledge economy, development and the future of higher education. Rotterdam: Sense Publishers.

Prober, C., \& Heath, C. (2012). Lecture halls without lectures-a proposal for medical education. New England Journal of Medicine, 366, 1657-1659.

Rindermann, H. (2007). Discussion on the g-factor of international cognitive ability comparisons: The homogeneity of results in PISA, TIMSS, PIRLS and IQ-tests across nations. European Journal of Personality, 21, 707-765.

Robinson, S. (2012). Self-plagiarism and unfortunate publication: an essay on academic values. Studies in higher education. doi: 10.1080/03075079.2012.655721.

Wegerif, R. B. (2007). Dialogic, education and technology: Expanding the space of learning. Berlin: Springer.

Wenger, E. (2000). Communities of practice: Learning, meaning, and identity. Cambridge, UK: Cambridge University Press. 